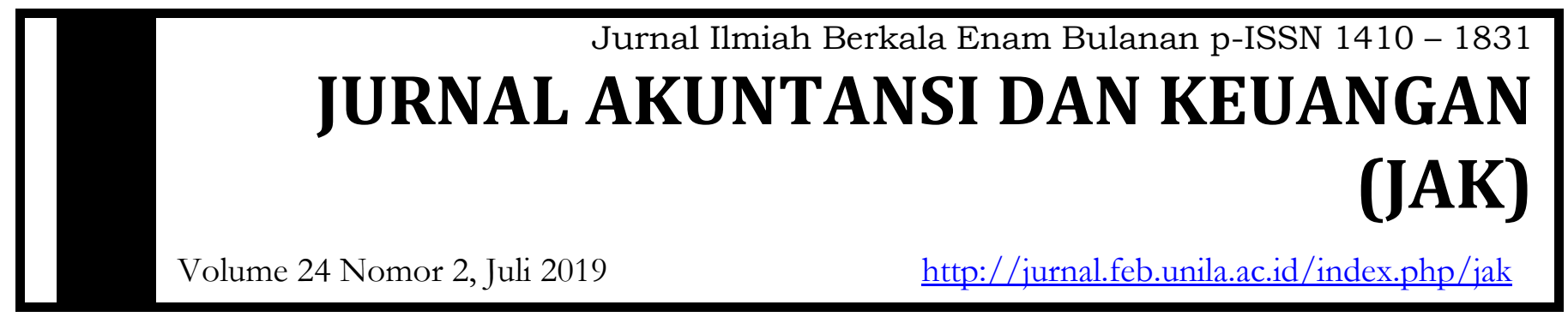

\title{
FAKTOR-FAKTOR YANG MEMPENGARUHI PENYUSUNAN LAPORAN KEUANGAN BERDASARKAN STANDAR AKUNTANSI KEUANGAN ENTITAS TANPA AKUNTABILITAS PUBLIK (SAK ETAP) PADA USAHA BARBERSHOP
}

\author{
Niken Kusumawardani ${ }^{1}$ \\ ${ }^{1}$ Fakultas Ekonomi dan Bisnis Universitas Lampung
}

\section{Informasi Naskah}

Update Naskah:

Dikumpulkan: 30 Mei 2019

Diterima: 30 Juni 2019

Terbit/Dicetak: 30 Juli 2019

\section{Keywords:}

Level of education, Educational background, Business scale, Business experience, and Entity Financial Accounting Standards without Public Accountability (SAK ETAP).

\section{$\underline{\text { Abstract }}$}

This research aims to; 1) Determine the effect of education level on the preparation of SAK ETAP financial statements; 2) Determine the influence of educational background on the preparation of SAK ETAP financial statements; 3) Determine the effect of business scale on the preparation of SAK ETAP financial statements; 4) Determine the effect of business experience on the preparation of SAK ETAP financial statements. The sample of this research is the Barbershop Micro, Small and Medium Enterprises (UMKM) in Tanjung Senang District. This sampling method uses random sampling. Data were analyzed using multiple linear regression analysis. The results showed that the level of education, educational background, and business scale did not significantly influence the preparation of SAK ETAP financial statements. Only business experience has a significant effect on the preparation of SAK ETAP financial statements. 


\section{A. PENDAHULUAN}

Dalam perekonomian Indonesia, Usaha Mikro, Kecil dan Menengah (UMKM) adalah kelompok usaha yang memiliki jumlah paling besar. Berdasarkan data yang dihimpun dari kementerian koperasi dan UMKM pada tahun 2014-2016 jumlah UMKM telah mencapai lebih dari 57.900.000 unit dan diperkirakan akan terus meningkat. Ditambah lagi kelompok usaha ini juga memiliki keunggulan yang sudah terbukti, mulai dari kemampuannya untuk menyerap tenaga kerja, ketahanan terhadap goncangan krisis ekonomi, dan berperan penting dalam perekonomian ASEAN, terbukti adanya beberapa UMKM Indonesia yang mampu menembus pasar dunia. Berdasarkan fenomena inilah UMKM terus menjamur di Indonesia.

Barbershop atau pangkas rambut merupakan salah satu jenis usaha mikro kecil dan menengah (UMKM) yang banyak bermunculan di kota Bandar Lampung. Hal ini dikarenakan iklim usaha yang kian kondusif dan juga pertumbuhan penduduk yang terjadi dari tahun ke tahun. Data pertumbuhan penduduk kota Bandar Lampung disajikan dalam tabel berikut ini:

Tabel 1 Jumlah Penduduk Kota Bandar Lampung Tahun 2011-2015

\begin{tabular}{cc}
\hline Tahun & Jumlah Penduduk (jiwa) \\
\hline \hline 2015 & 979.287 \\
2014 & 960.695 \\
2013 & 942.039 \\
2012 & 902.885 \\
2011 & 891.374 \\
\hline
\end{tabular}

Sumber: https://bandarlampungkota.bps.go.id di update 10 Jan 2018

Faktor lain yang menjadi alasan menjamurnya iklim usaha barbershop adalah kebutuhan masyarakat akan jasa pangkas rambut yang semakin meningkat, yaitu semakin banyak jenis usaha sejenis yang muncul sehingga meningkatkan persaingan antar usaha sejenis. Dalam usaha mempertahankan keberlangsungan usaha dibutuhkan kesiapan tersendiri dari pelaku usaha tersebut. Para pelaku usaha barbershop tidak hanya dituntut meningkatkan kualitas pelayanan namun juga mampu menjalankan operasional perusahaan secara efektif dan efisien. Salah satu upaya menjalankan operasional efektif dan efisien, manajemen mampu memberikan informasi keuangan yang transparan dan akuntabel. Produk berupa laporan keuangan menjadi salah satu sarana yang mampu menjawab kebutuhan tersebut. Laporan keuangan memberikan informasi terkait sumber daya dan penggunaan dalam operasional usaha.

Standar Akuntansi Keuangan Entitas Tanpa Akuntabilitas Publik (SAK ETAP) merupakan pedoman standar keuangan yang bertujuan mempermudah UMKM dalam menyusun dan menyajikan laporan keuangan yang lebih implementatif. Laporan keuangan ditujukan bagi pihak internal maupun eksternal. Bagi pihak internal, salah satunya memudahkan manajemen dalam memperhitungkan keuntungan dan kerugian dalam aktivitas operasi dan mengetahui pos-pos penerimaan dan pengeluaran secara terinci, sedangkan bagi pihak eksternal memudahkan para investor untuk memberikan pembiayaan bagi para pengusaha UMKM. Sehubungan dengan diberlakukannya IFRS di Indonesia, maka entitas bisnis tanpa akuntabilitas publik, seperti UMKM dan koperasi, dalam penyusunan dan penyajian laporan keuangannya mengacu pada SAK ETAP, yaitu: (1) diperuntukkan bagi entitas tanpa akuntabilitas publik, (2) pengaturannya lebih sederhana, mengatur transaksi umum yang tidak kompleks, (3) perbedaan dengan PSAK No.27/1998 tidak ada kewajiban koperasi menyusun dan menyajikan Laporan Promosi Ekonomi Anggota (LPEA), (4) Laporan Keuangan dengan ETAP, yaitu Neraca, Perhitungan Hasil Usaha, Laporan Arus Kas, Laporan Perubahan Ekuitas dan Catatan atas Laporan Keuangan. Pemberlakuan Standar Akuntansi Keuangan Entitas Tanpa Akuntabilitas Publik (SAK ETAP) tergolong masih baru, maka hal terpenting dari proses implementasi SAK ETAP adalah adanya pemahaman yang baik akan isi aturan SAK ETAP terlebih dahulu, sebelum digunakan dalam usahanya. Namun, pada kenyataannya masih banyak UMKM yang belum menyajikan laporan keuangannya berdasarkan SAK ETAP bahkan masih banyak yang belum mampu menyajikan sesuai dengan standar yang ada. 
Solovida (2003) melakukan penelitian terhadap penyiapan dan penggunaan informasi akuntansi pada perusahaan kecil dan menegah di Jawa Tengah. Hasil penelitiannya mengemukakan bahwa masa memimpin perusahaan, pendidikan formal pemilik/manajer, pelatihan akuntansi yang diikuti pemilik/manajer, umur perusahaan dan budaya organisasi berpengaruh signifikan terhadap penyiapan dan penggunaan informasi akuntansi. Tuti dan Dwijayanti (2014) melakukan penelitian mengenai faktor-faktor yang mempengaruhi pemahaman UMKM dalam menyusun laporan keuangan berdasarkan SAK ETAP. Hasil penelitian menunjukkan bahwa hanya variabel lama usaha yang memiliki pengaruh signifikan terhadap pemahaman UMKM dalam menyusun laporan keuangan berdasarkan SAK ETAP. Sedangkan latar belakang pendidikan, jenjang pendidikan, pemberian informasi dan sosialisasi, dan ukuran usaha tidak berpengaruh signifikan terhadap variabel dependen penelitian tersebut. Sebagian besar responden penelitian menyatakan belum pernah mendapatkan sosialisasi/informasi mengenai SAK ETAP.

Kholis (2014) melakukan penelitian dengan metode studi kasus pada UKM Tepung Tapioka di Desa Ngemplak Kidul Kecamatan Margoyoso Kabupaten Pati. Dari hasil analisis menunjukkan bahwa, variabel independen yang berpengaruh positif dan signifikan hanya variabel tingkat pendidikan dan pengalaman usaha, sedangkan variabel skala usaha dan masa jabatan tidak berpegaruh signifikan terhadap penerapan laporan informasi akuntansi.

Oktariatama (2015) melakukan penelitian terhadap faktor-faktor yang mempengaruhi pemahaman bagian akuntansi koperasi atas standar akuntansi keuangan tanpa akuntabilias publik pada koperasi di Kabupaten Purworejo. Hasil penelitian menunjukkan bahwa Hasil penelitian menunjukan jenjang pendidikan, pemberian informasi dan sosialisasi, dan masa tugas pekerjaan bagian akuntansi koperasi berpengaruh secara positif signifikan terhadap pemahaman atas SAK ETAP, sedangkan variabel latar belakang pendidikan bagian akuntansi koperasi tidak berpengaruh positif terhadap pemahaman atas SAK ETAP. Berdasarkan fenomena dan kajian penelitian terdahulu maka penelitian ini dilakukan.

\section{B. LANDASAN TEORI DAN PENGEMBANGAN HIPOTESIS}

Business Entity atau Entity Concept merupakan konsep dasar akuntansi yang menyatakan bahwa entitas akuntansi adalah organisasi yang terpisah dari kepentingan pemilik. Konsep ini menitikberatkan pada pemisahan transaksi bisnis perusahaan dengan transaksi bisnis pemilik. Operasional perusahaan terpisah dari kepentingan pribadi pemilik. Informasi akuntansi harus didasarkan pada data yang paling dapat diandalkan. Pedoman ini berdasarkan pada prinsip reliabilitas (reliability principle). Data yang andal adalah data yang dapat diverifikasi artinya memiliki bukti pendukung yang menguatkan kejadian tersebut. Prinsip biaya (cost principle) adalah aktiva atau jasa yang diperoleh harus didasarkan pada biaya aktualnya atau biaya perolehannya.

Menurut Ajzen (1991) Theory Planned of Behavior (TPB) ini didasarkan pada asumsi bahwa manusia biasanya akan berperilaku pantas (behave in a sensible manner) karena manusia adalah makhluk rasional yang mampu menggunakan informasi-informasi secara sistematis untuk memikirkan implikasi dari tindakan mereka untuk berperilaku tertentu. Berdasarkan Theory Planned of Behavior (TPB), sikap seseorang merupakan kepercayaan positif atau negatif untuk menampilkan suatu perilaku tertentu sehingga memunculkan intense untuk berperilaku yang ditentukan oleh sikap. SAK ETAP dibuat dengan tujuan membantu proses penyelenggaraan akuntansi secara lebih mudah dan sederhana bagi entitas tanpa akuntabilitas publik. Hal ini diharapkan mampu mempengaruhi penggunaan SAK ETAP pada usaha barbershop dalam menyajikan laporan keuangan.

Theory Planned of Behavior (TPB) juga menjelaskan bahwa sebagai makhluk yang mampu berfikir logis dan rasional, manusia cenderung menggunakan informasi yang diperolehnya secara sistematis untuk memikirkan implikasi tindakan dan pengambilan keputusan strategis. Penggunaan SAK ETAP dalam penyusunan laporan keuangan sebagai upaya peningkatan kualitas laporan keuangan yang dihasilkan sehingga para pelaku usaha barbershop dapat merasakan dampak terhadap proses pengidentifikasian transaksi dan penyajiannya.

Standar Akuntansi Entitas Tanpa Akuntabilitas Publik (SAK ETAP) dalam SAK ETAP (2009) 
Standar Akuntansi Keuangan Tanpa Akuntabilitas Publik (SAK ETAP) dimaksudkan untuk digunakan entitas tanpa akubilitas publik. Entitas tanpa akuntabilitas publik adalah entitas yang: tidak memiliki akuntabilitas publik signifikan dan menerbitkan laporan keuangan untuk tujuan umum (general purpose financial statement) bagi pengguna eksternal. Contoh pengguna eksternal adalah pengguna yang tidak terlibat langsung dalam pengelolaan perusahaan, yaitu: investor, lembaga pembiayaan, pemerintah, masyarakat dll.

SAK ETAP diterapkan untuk penyusunan laporan keuangan yang dimulai pada atau setelah 1 Januari 2011. Penerapan lebih cepat diperkenankan. Komponen laporan keuangan yang disajikan menurut SAK ETAP tidak memiliki perbedaan yang signifikan, yaitu: neraca, laporan laba/rugi, laporan perubahan ekuitas dan laporan arus kas. IAI (2009) menjelaskan tujuan laporan keuangan adalah menyediakan informasi posisi keuangan, kinerja keuangan dan laporan arus kas suatu entitas yang bermanfaat bagi sejumlah besar pengguna dalam pengambilan keputusan ekonomi oleh siapapun yang tidak dalam posisi dapat meminta laporan keuangan khusus untuk memenuhi kebutuhan informasi tertentu. Dalam memenuhi tujuannya laporan keuangan juga menunjukkan apa yang telah dilakukan manajemen atau pertanggungjawaban manajemen atau sumber daya yang dipercayakan kepadanya.

Usaha Mikro Kecil dan Menengah (UMKM) menurut UU Republik Indonesia No.20 yang ditetapkan tanggal 4 Juli 2008 mengatur tentang Usaha Mikro, Kecil dan Menengah. Yang disebut dengan usaha mikro adalah entitas yang memiliki kriteria sebagai berikut:

1. Kekayaan bersih maksimal Rp50.000.000 (Lima puluh juta rupiah)

2. Memiliki hasil penjualan tahunan maksimal Rp300.000.000

Usaha Kecil adalah entitas yang memiliki kriteria sebagai berikut:

1. Kekayaan bersih lebih dari Rp50.000.000 sampai dengan paling banyak Rp500.000.000

2. Memiliki hasil penjualan tahunan lebih dari Rp300.000.000 sampai dengan paling banyak Rp2.500.000.000

Usaha Menengah adalah entitas usaha yang memiliki kriteria sebagai berikut:

1. Kekayaan bersih lebih dari Rp500.000.000 sampai dengan paling banyak Rp10.000.000.000 tidak termasuk tanah dan bangunan tempat usaha

2. Memiliki hasil penjualan tahunan lebih dari Rp2.500.000.000 sampai dengan paling banyak Rp50.000.000.000

Kemudahan daya tangkap seseorang dalam menerima suatu hal baru dipengaruhi oleh tingkat pendidikan seseorang. Seseorang dengan jenjang pendidikan tinggi akan terbiasa memahami hal baru dengan lebih mudah dan cepat dibanding orang-orang yang memiliki jenjang pendidikan yang lebih rendah. Hal ini sesuai dengan penelitian Gray (2006) dan Van Hermet et al. (2011) menyatakan bahwa kemampuan seseorang dalam menyerap pengetahuan baru akan meningkat jika memiliki jenjang pendidikan yang lebih tinggi.Solovida (2003) menyatakan kemampuan dan keahlian pemilik atau manajer perusahaan kecil dan menengah ini sangat ditentukan dari pendidikan formal yang pernah ditempuh. Andriani et al (2015) dalam hasil penelitiannya menyatakan bahwa semakin tinggi tingkat pendidikan formal manajer dalam usaha UMKM, maka semakin memahami penggunaan informasi akuntansi.Hipotesis ini didukung oleh hasil penelitian sebelumnya yaitu penelitian yang dilakukan oleh Rudiantoro dan Siregar (2011) yang menyatakan bahwa jenjang pendidikan terakhir berpengaruh positif signifikan terhadap pemahaman SAK ETAP. Pratiwi et al (2016) menyatakan bahwa pendidikan pemilik UMKM berpengaruh signifikan terhadap penerapan SAK ETAP.Berdasarkan uraian teoritis dan beberapa penelitian maka hipotesis pertama dinyatakan:

\section{H1: Tingkat pendidikan berpengaruh terhadap penyusunan laporan keuangan berdasarkan SAK ETAP}

Theory Planned Of Behavior mengasumsikan bahwa manusia sebagai makhluk yang mampu berfikir rasional menggunakan informasi yang diperolehnya untuk memikirkan implikasi dari tindakan mereka sebelum mengambil keputusan. Teori ini membantu menjelaskan pengaruh latar belakang 
pendidikan yang dimiliki para pelaku usaha barbershop yang dijadikan sebagai sumber dasar pengetahuan dan informasi yang mampu memudahkan dalam memahami isi aturan SAK ETAP.Hipotesis ini didukung oleh hasil penelitian Aufar (2014) yang membuktikan latar belakang pendidikan berpengaruh positif signifikan terhadap penggunaan informasi akuntansi. Andriani, et al (2014) juga menyatakan bahwa latar belakang pendidikan merupakan faktor internal yang memiliki pengaruh cukup besar dalam proses implementasi dan pencatatan laporan keuangan berbasis SAK ETAP pada UMKM.Rudiantoro dan Siregar (2012) menyatakan bahwa pengusaha UMKM yang berlatar belakang pendidikan non akuntansi cenderung lebih lama dalam memahami proses penyusunan laporan keuangan berdasarkan SAK ETAP. Oleh karena itu, bagian akuntansi koperasi yang berlatarbelakang pendidikan akuntansi diyakini mempunyai pemahaman yang lebih baik mengenai SAK ETAP. Berdasarkan hal tersebut, maka hipotesis yang dapat dirumuskan adalah:

\section{$\mathrm{H}_{2}$ : Latar belakang pendidikan berpengaruh terhadap penyusunan laporan keuangan berdasarkan SAK ETAP}

Setiyadi (2007) menyatakan skala usaha yang bisa dipakai untuk menentukan tingkatan perusahaan adalah: (a) tenaga kerja, merupakan jumlah pegawai tetap dan honorer yang terdaftar atau bekerja di perusahaan pada suatu saat tertentu; (b) tingkat penjualan merupakan volume penjualan suatu perusahaan pada suatu periode tertentu; (c) total utang merupakan jumlah utang perusahaan pada periode tertentu; (d) total aset merupakan keseluruhan aset yang dimiliki perusahaan pada saat tertentu. Hasil penelitian Murniati (2002) menemukan adanya pengaruh yang positif signifikan antara skala usaha dan penyediaan dan penggunaan informasi akuntansi. Demikian juga dengan penelitian Holmes dan Nicholls (1988) menyatakan bahwa skala usaha berpengaruh positif terhadap tingkat penyediaan informasi akuntansi. Hal ini diperkuat juga dari hasil penelitian Mulyaga (2016) yang menyatakan bahwa skala usaha berpengaruh positif terhadap implementasi SAK ETAP. Berdasarkan kajian tersebut, maka hipotesis yang dibuat adalah:

\section{H3 : Skala usaha berpengaruh terhadap penyusunan laporan keuangan berdasarkan SAK ETAP}

Salah satu fungsi dasar Theory Planned of Behavior (TPB) yaitu perceived behavioral control yang berkaitan dengan pengalaman masa lalu dan persepsi seseorang untuk menentukan perilakunya. Kaitan dalam penelitian ini adalah pengalaman usaha yang diperoleh selama menjalankan usaha diharapkan mampu meningkatkan persepsi pemilik usaha barbershop terhadap isi aturan SAK ETAP dan mengimplementasikannya. Foster (2001) menyatakan lama waktu atau masa kerja, tingkat pengetahuan dan ketrampilan yang dimiliki, serta jenis pekerjaan dapat menunjukkan pengalaman kerja seseorang. Orang yang dikatakan berpengalaman mempraktekkan teori yang pernah didapat dari hasil proses belajar atau berpendidikan sehingga diharapkan dapat berkontribusi ditempatnya bekerja. Penelitian Wijayanti (2015) juga menemukan bahwa masa tugas pekerjaan berpengaruh terhadap implementasi SAK ETAP. Sigit (2017) menyatakan bahwa pengalaman kerja berpengaruh terhadap tingkat kemampuan pemahaman SAK ETAP. Jadi, dapat disimpulkan bahwa pelaku usaha barbershop dengan pengalaman usaha yang lama akan lebih memahami penyusunan laporan keuangan berdasarkan SAK ETAP.

\section{$\mathrm{H}_{4}$ : Pengalaman usaha berpengaruh terhadap penyusunan laporan keuangan berdasarkan SAK ETAP}

\section{METODE PENELITIAN}

Metode yang digunakan yang digunakan dalam penelitian ini adalah metode kuantitatif. Menurut Sugiyono (2012) metode kuantitatif merupakan sumber data penelitian berupa angka-angka dan analisis yang menggunakan statistik. Penelitian ini dilakukan melalui penggunaan data primer yang diperoleh berdasarkan penyebaran kuesioner kepada responden, yaitu para pelaku usaha barbershop di wilayah Kota Bandar Lampung. Penyebaran kuesioner dilakukan untuk memperoleh informasi mengenai pengaruh tingkat pendidikan $\left(\mathrm{X}_{1}\right)$, latar belakang pendidikan $\left(\mathrm{X}_{2}\right)$, skala usaha $\left(\mathrm{X}_{3}\right)$, pengalaman usaha $\left(\mathrm{X}_{4}\right)$ terhadap 
penyusunan laporan keuangan SAK ETAP (Y). Menurut Sugiyono (2012) populasi adalah wilayah generalisasi yang terdiri atas obyek atau subyek yang mempunyai kualitas dan karakteristik tertentu yang ditetapkan oleh peneliti untuk dipelajari dan kemudian ditarik kesimpulannya. Dalam penelitian ini, populasi yang diambil adalah pengusaha barbershop yang ada di Kecamatan Tanjung Senang.

Pada penelitian ini terdapat variabel independen (bebas) dan variabel dependen (terikat). Menurut Sanusi (2016) variabel independen atau variabel bebas adalah variabel yang mempengaruhi variabel lain, sedangkan variabel dependen atau variabel terikat adalah adalah variabel yang dipengaruhi oleh variabel lain. Dalam penelitian ini, variabel independen atau variabel bebas diwakilkan oleh tingkat pendidikan $\left(\mathrm{X}_{1}\right)$, latar belakang pendidikan $\left(\mathrm{X}_{2}\right)$, skala usaha $\left(\mathrm{X}_{3}\right)$, dan pengalaman usaha $\left(\mathrm{X}_{4}\right)$. Variabel dependen atau variabel terikat diwakilkan oleh penyusunan laporan keuangan SAK ETAP (Y). Seluruh variabel dalam penelitian ini akan diukur menggunakan instrumen penelitian dalam bentuk kuesioner. Kuesioner merupakan hasil telaah penelitian terdahulu dan analisis peneliti dalam mengukur tiap-tiap variabel yang digunakan.

Analisis data yang dilakukan dalam penelitian ini menggunakan pengujian statistik regresi berganda. Sebelum dianalisis secara statistik data terlebih dahulu diuji validitas dan reliabilitasnya. Menurut Nunally (1969) dalam Ghozali (2001), suatu konstruk atau variabel dikatakan reliabel, jika memberikan nilai cronbach alpha $>0$, 60, sedangkan validitas dalam penelitian ini diukur dengan digunakan coeficient corelation pearson yaitu dengan menghitung korelasi antara skor masing-masing butir pertanyaan dengan total skor (Ghozali, 2001). Ini menggambarkan instrumen penelitian yang dipakai semua valid.

Metode statistik yang digunakan untuk menguji hipotesis yang diajukan dalam penelitian ini adalah regresi berganda (multiple regression) dengan bantuan program SPSS 22.

Model persamaan regresi dalam penelitian ini adalah sebagai berikut :

$$
Y=\alpha+\beta_{1} X_{1}+\beta_{2} X_{2}+\beta_{3} X_{3}+\beta_{4} X_{4}+\varepsilon
$$

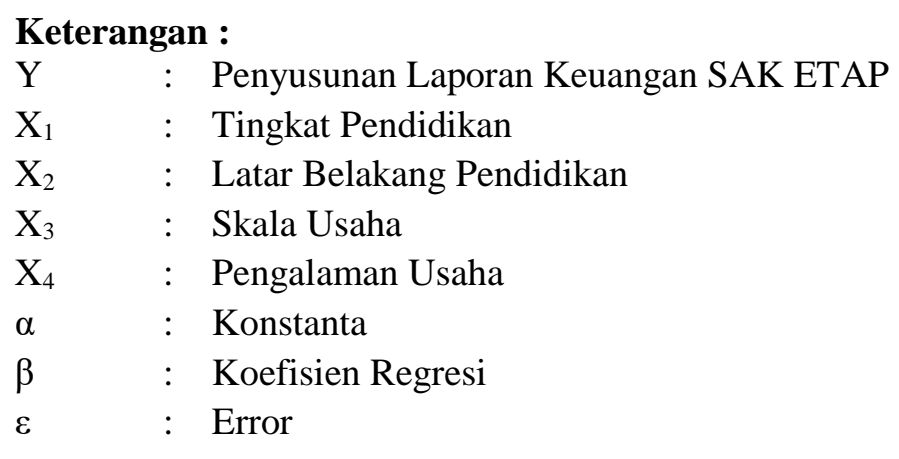

\section{ANALISIS DAN PEMBAHASAN}

UMKM barbershop yang ada di kecamatan Tanjung Senang pada umumnya beranggotakan lima atau enam orang, yang memiliki tugas sebagai pemangkas rambut dan satu orang selaku kasir. Rata-rata pendapatan per tahun kurang dari Rp100.000.000. Responden penelitian seluruhnya laki-laki, mulai dari pemilik hingga karyawan usaha barbershop.

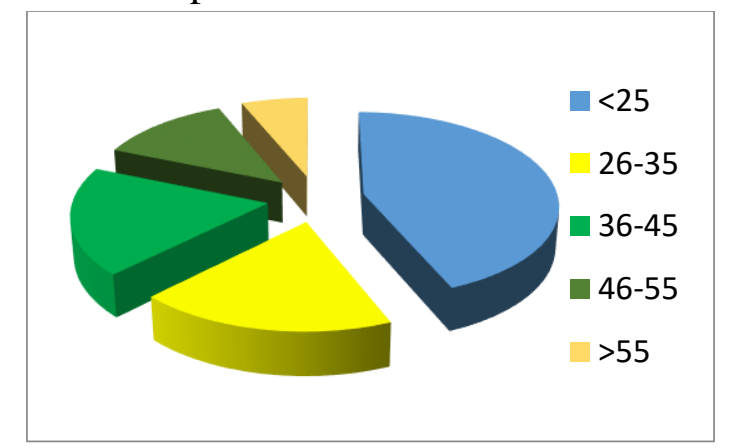

Gambar 1 Profil Responden Berdasarkan Umur

Sumber: Data primer yang diolah, 2018 
Gambar 1 menunjukkan bahwa responden dalam penelitian ini memiliki sebaran rentang umur sebagai berikut, kelompok umur dalam rentang < 25 tahun, yaitu sebanyak 7 orang atau $47 \%$ responden. Sedangkan kelompok umur dalam rentang 26-35 tahun, yaitu sebanyak 3 orang atau 20\% responden. Kelompok umur dalam rentang 36-45 tahun, yaitu sebanyak 3 orang atau $20 \%$ responden. Kelompok umur dalam rentang 46-55 tahun, yaitu sebanyak 2 orang atau 13\% responden dan kelompok umur $>55$ tahun, yaitu sebanyak 1 orang atau $7 \%$ responden. Profil responden berdasarkan jenjang pendidikan ditunjukkan pada gambar 2.

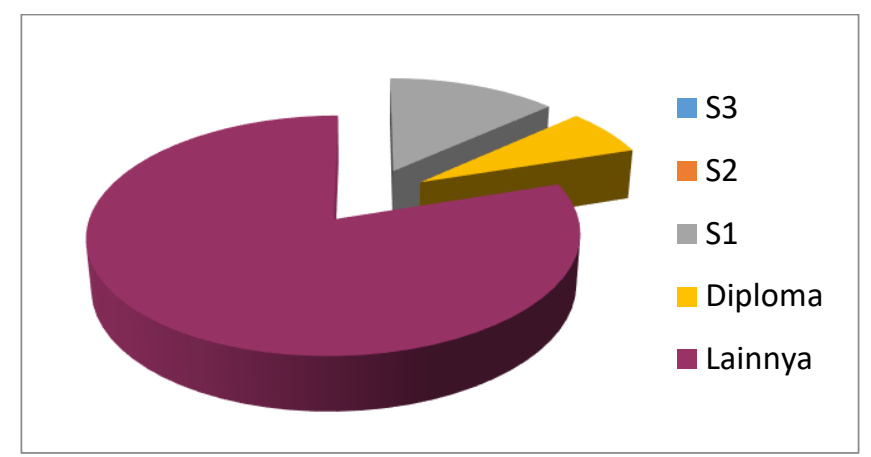

Gambar 2 Profil Responden Berdasarkan Jenjang Pendidikan Sumber: Data primer yang diolah, 2017

Gambar 2 menunjukkan bahwa responden penelitian yang memiliki jenjang pendidikan S1 sebanyak 2 orang atau $13 \%$ responden, sedangkan responden yang memiliki jenjang pendidikan Diploma sebanyak 1 orang atau $7 \%$ responden, dan sebanyak $80 \%$ responden atau berjumlah 12 orang adalah memiliki jenjang pendidikan SMA atau sederajat atau SMP. Untuk jenjang pendidikan S3 tidak ada responden yang memiliki jenjang pendidikan tersebut. Profil responden berdasarkan masa kerja ditunjukkan dalam gambar 3.

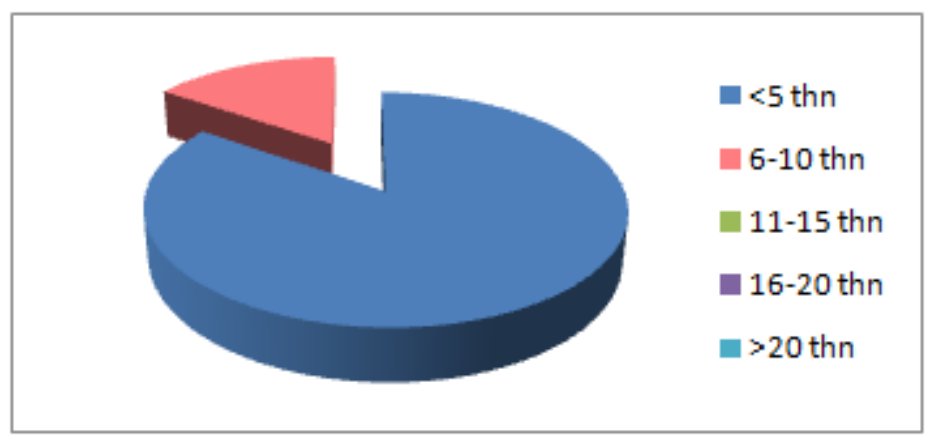

Gambar 3 Profil Responden Berdasarkan Pengalaman usaha

Sumber: Data primer yang diolah, 2017

Gambar 4 menunjukkan bahwa responden penelitian sebagian besar memiliki pengalaman kerja atau usaha dalam rentang waktu $<5$ tahun, yaitu sebanyak 11 orang atau sebesar $73 \%$, kemudian responden yang memiliki masa kerja 6-10 tahun sebanyak 2 orang atau sebesar 13\%, sedangkan tidak ada responden yang memiliki masa kerja 11-15 tahun, 16-20 tahun dan > 20 tahun.

Uji validitas digunakan untuk mengkur sah atau valid tidaknya suatu kuesioner. Suatu kuesioner dinyatakan valid jika pertanyaan pada kuesioner mampu untuk mengungkapkan sesuatu yang akan diukur oleh kuesioner tersebut. Untuk mengukur tingkat validitas dari setiap pertanyaan digunakan cooeficient correlation pearson yaitu dengan menghitung masing-masing skor dari setiap butir pertanyaan dengan skor total nya (Ghozali, 2007). Hasil pengujian menggunakan program SPSS22 menunjukkan nilai cooeficient correlation pearson pada masing-masing variabel dapat dilihat pada tabel uji validitas. Dari hasil pengolahan data uji validitas variabel penelitian seluruh pertanyaan yang mewakili variabel penelitian memiliki nilai signifikansi < 0,05.Hal ini menunjukkan bahwa korelasi antara masing-masing indikator terhadap total skor konstruk menunjukkan hasil yang signifikan dapat disimpulkan bahwa masing-masing butir pertanyaan pada variabel konstruk penelitian adalah valid. 
Uji reliabilitas digunakan untuk mengukur suatu kuesioner yang merupakan indikator dari variabel atau konstruk. Suatu kuesioner dikatakan reliabel atau handal jika jawaban seseorang terhadap pernyataan adalah konsisten atau stabil dari waktu ke waktu (Ghozali, 2007). Pengujian dilakukan dengan metode pengukuran sekali saja, artinya pertanyaan hanya diberikan satu kali saja kemudian hasilnya dibandingkan dengan dengan pertanyaan lain atau mengukur korelasi antar jawaban pertanyaan. Untuk mengukur reliabilitas dapat dilakukan dengan uji statistik Cronbach Alpha (á). Menurut Nunnally (1960) dalam Ghozali (2007) suatu konstruk atau variabel dikatakan reliabel jika memberikan Cronbach Alpha > 0, 60. Hasil pengujian menggunakan SPSS 22 menunjukkan nilai Cronbach Alpha variabel penelitian sebagai berikut:

Tabel 2 Hasil Reliabilitas Variabel Penelitian

\begin{tabular}{lccc}
\hline \multicolumn{1}{c}{ Variabel } & Cronbach Alpha & Koefisien Reliabilitas & Keterangan \\
\hline \hline Tingkat pendidikan (X1) & 0,739 & 0,60 & Reliabel \\
Latar belakang pendidikan (X2) & 0,613 & 0,60 & Reliabel \\
Skala usaha (X3) & 0,716 & 0,60 & Reliabel \\
Pengalaman usaha (X4) & 0,660 & 0,60 & Reliabel \\
Penyusunan laporan keuangan SAK ETAP (Y) & 0,756 & 0,60 & Reliabel \\
\hline \hline
\end{tabular}

Sumber: Data primer yang diolah, 2018

Berdasarkan tabel hasil reliabilitas variabel penelitian dapat diketahui bahwa nilai koefisien Cronbach Alpha variabel penelitian masing-masing lebih besar dari 0, 60 yang artinya bahwa data yang dikumpulkan dengan menggunakan instrumen atau kuesioner tersebut reliabel. Setelah melakukan uji validitas dan reliabilitas maka dilakukan uji asumsi klasik. Uji asumsi klasik dilakukan terlebih dahulu dalam pengujian hipotesis yang menggunakan alat uji regresi linear berganda.

Dalam penelitian ini terdapat empat hipotesis yang akan diuji yaitu, apakah variabel tingkat pendidikan, latar belakang pendidikan, skala usaha dan pengalaman usaha berpengaruh terhadap penyusunan laporan keuangan berdasarkan SAK ETAP. Pengujian hipotesis menggunakan analisis regresi berganda (multiple regressions) yaitu dengan melihat tingkat signifikansi dari masing-masing pengaruh variabel independen terhadap variabel dependen, maka dapat diketahui bahwa hipotesis diterima atau hipotesis ditolak. Hasil uji hipotesis SPSS 22 disajikan dalam tabel berikut ini:

Tabel 3 Hasil Analisis Regresi Berganda Terhadap Penyusunan Laporan Keuangan Berdasarkan SAK ETAP

\begin{tabular}{llccc}
\hline Model & \multicolumn{1}{c}{ Variabel } & $\begin{array}{c}\text { Standardized Coeficient } \\
\text { Beta }\end{array}$ & $\mathrm{t}$ & Sig \\
& & 0,127 & 0,568 & 0,576 \\
\hline \hline Tingkat pendidikan (X1) & 1,183 & 0,817 & 0,423 \\
Latar belakang pendidikan (X2) & 0,106 & 1,328 & 0,19 \\
Skala usaha (X3) & 0,125 & 0,037 & 0,046 \\
Pengalaman usaha (X4) & Sig:0,463 & & \\
F : 4,920 & & & \\
R: 0,704 & & & \\
R square : 0,496 & & & \\
Adj. R. square : 0,395
\end{tabular}

Sumber: Data primer yang diolah, 2018

Berdasarkan tabel hasil analisis regresi berganda diperoleh nilai Adjusted $\mathrm{R} 2$ pada variabel dependen penyusunan laporan keuangan SAK ETAP adalah 0.395, hal ini berarti bahwa 39,5\% variasi penyusunan laporan keuangan SAK ETAP dapat dijelaskan dari empat variabel independen yaitu tingkat pendidikan, latar belakang pendidikan, skala usaha dan pengalaman usaha. Sedangkan sisanya yaitu 60,5\% dijelaskan oleh sebab-sebab lain diluar model. Hasil uji ANOVA atau uji F menunjukkan angka 4,920 dengan $p$ - 
value 0,463. Hal ini menunjukkan bahwa variabel-variabel independen dalam penelitian ini dapat digunakan memprediksi variabel dependennya. Pengujian terhadap keempat hipotesis dapat dilihat dari nilai koefisien $\beta$ dan $p$-value (signifikan $\mathrm{t}$ ) dari tiap-tiap variabel independen. Apabila nilai positif maka terdapat hubungan positif, demikian juga sebaliknya. Apabila p-value lebih kecil dari tingkat alpha yang digunakan, maka hipotesis alternatif berhasil didukung. Tingkat keyakinan (confidence interval) yang digunakan dalam penelitian ini adalah 95\% $(\alpha=5 \%)$, yang berarti mentoleransi tingkat penyimpangan maksimum 5\%. Untuk pengujian tersebut menggunakan program software SPSS22.

Hipotesis 1 menyatakan bahwa tingkat pendidikan berpengaruh terhadap penyusunan laporan keuangan SAK ETAP. Pada tabel 4.4.1 menunjukkan ekspektasi kinerja ekspektasi kinerja mempunyai nilai $\rho=0,576$ dengan koefisien regresi sebesar 0,127 , sehingga hipotesis 1 ditolak, karena nilai $\rho$ menunjukkan nilai yang lebih besar dari 0,1 . Maka dapat disimpulkan bahwa tingkat pendidikan tidak mempunyai pengaruh terhadap penyusunan laopran keuangan SAK ETAP. Hasil pengujian hipotesis 1 ini menggambarkan bahwa dengan tingkat pendidikan yang dimiliki oleh pelaku UMKM Barbershop tidak mendorong terjadinya penyusunan laporan keuangan berdasarkan SAK ETAP. Hal ini membawa konsekuensi bagi para pelaku UMKM Barbershop, untuk lebih memiliki kesadaran diri dalam penyusunan laporan keuangan SAK ETAP, sehingga pada akhirnya laporan keuangan yang dihasilkan dapat diandalkan dan relevan. Pengujian hipotesis 1 memberikan hasil yang sama dengan penelitian sebelumnya yang dilakukan oleh Tuti (2014) yang mendapatkan hasil bahwa jenjang pendidikan tidak berpengaruh signifikan terhadap penyusunan laporan keuangan berdasarkan SAK ETAP. Hal ini disebabkan, jenjang pendidikan seseorang juga mempengaruhi skill dan pengetahuan seseorang. Para pelaku UMKM Barbershop kebanyakan hanya menempuh pendidikan SMA/SMK dan tidak berlatar belakan ekonomi akuntansi dan manajemen.

Hipotesis 2 menyatakan latar belakang pendidikan berpengaruh terhadap penyusunan laporan keuangan SAK ETAP. Dalam tabel 4.4.1 menunjukkan latar belakang pendidikan mempunyai nilai $\rho=$ 0,423 dengan koefisien regresi sebesar 0,817, sehingga hipotesis 2 ditolak. Hal ini menunjukkan bahwa latar belakang pendidikan tidak mempunyai pengaruh terhadap penyusunan laporan keuangan SAK ETAP. Rudiantoro dan Siregar (2012) menyatakan bahwa pengusaha UMKM yang berlatarbelakang pendidikan non akuntansi cenderung lebih lama dalam memahami proses penyusunan laporan keuangan berdasarkan SAK ETAP. Oleh karena itu, bagian akuntansi koperasi yang berlatarbelakang pendidikan akuntansi diyakini mempunyai pemahaman yang lebih baik mengenai SAK ETAP. Dalam UMKM Barbershop banyak didominasi oleh para pelaku usaha diluar latar belakang pendidikan non akuntansi bahkan ada yang sudah pensiunan, sehingga penyusunan laporan keuangan berdasarkan SAK ETAP sangat sulit untuk dilakukan.

Hipotesis 3 menyatakan bahwa skala usaha berpengaruh terhadap penyusunan laporan keuangan SAK ETAP. Dalam tabel 4.4.1 menunjukkan skala usaha mempunyai nilai $\rho=0,19$ dengan koefisien regresi sebesar 0,106, sehingga hipotesis 3 ditolak. Nilai koeefisien bertanda positif dan signifikansi $>0,05$ menunjukkan bahwa skala usaha tidak berpengaruh terhadap penyusunan laporan keuangan SAK ETAP pada UMKM Barbershop. Hal ini konsisten dengan hasil penelitian Prawesti (2017) skala usaha tidak berpengaruh signifikan terhadap pemahaman UMKM dalam menyusun laporan keuangan berdasarkan SAK ETAP di Kabupaten Sleman.

Hipotesis 4 menyatakan bahwa pengalaman usaha berpengaruh terhadap penyusunan laporan keuangan SAK ETAP. Dalam tabel 4.4.1 menunjukkan pengalaman usaha mempunyai nilai $\rho=0,046$ dengan koefisien regresi sebesar 0,125, sehingga hipotesis 4 diterima, artinya bahwa variabel ini secara signifikan berpengaruh terhadap penyusunan laporan keuangan SAK ETAP. Hasil pengujian hipotesis 4 ini memberikan gambaran bahwa pengalaman usaha UMKM Barbershop mampu memberikan kontrubusi yang positif terhadap penyusunan laporan keuangan, pengalaman usaha yang relatif masih sedikit kurang dari lima tahun menjadi penyebab kurangnya perhatian terhadap penyusunan laporan keuangan SAK ETAP pada UMKM Barbershop. Hal ini konsisten dengan hasil penelitian Wijayanti (105) yang menyatakan 
bahwa masa tugas pekerjaan berpengaruh terhadap implementasi SAK ETAP. Sigit (2017) menyatakan bahwa pengalaman kerja berpengaruh terhadap tingkat kemampuan pemahaman SAK ETAP. Namun hasil penelitian ini tidak konsisten dengan hasil penelitian Susanto dan Yuliani (2012) serta penelitian Zahri 2014 bahwa umur usaha tidak berpengaruh terhadap persepsi pengusaha terkait laporan keuangan.

Dari hasil pengolahan data, output SPSS22 yang dihasilkan diperoleh persamaan regresi sebagai berikut:

$$
\mathrm{Y}=0,127 \mathrm{X} 1+1,183 \mathrm{X} 2+0,106 \mathrm{X3}+0,125 \mathrm{X}_{4}+\mathrm{e}
$$

Adapun hasil pengujian hipotesis adalah sebagai berikut :

Tabel 3 Hasil Pengujian Hipotesis

\begin{tabular}{lll}
\hline & \multicolumn{1}{c}{ Hipotesis } & \multicolumn{1}{c}{ Kesimpulan } \\
\hline \hline H1 & Tingkat pendidikan berpengaruh terhadap penyusunan SAK ETAP & Hipotesis Ditolak \\
H2 & Latar belakang pendidikan berpengaruh terhadap penyusunan SAK ETAP & Hipotesis Ditolak \\
H3 & Skala usaha berpengaruh terhadap penyusunan SAK ETAP & Hipotesis Ditolak \\
H4 & Pengalaman usaha berpengaruh terhadap penyusunan SAK ETAP & Hipotesis Diterima \\
\hline \hline
\end{tabular}

Sumber: Hasil Penelitian, 2018

Dari tabel hasil pengujian hipotesis dapat dilihat bahwa tingkat pendidikan berpengaruh positif signifikan terhadap penyusunan laporan keuangan SAK ETAP, namun dari hasil pengujian dinyatakan ditolak, artinya tidak ada pengaruh antara tingkat pendidikan dengan penyusunan laporan keuangan SAK ETAP. Tingkat pendidikan yang mayoritas bukan lulusan S1 dan Diploma membuat tingkat pendidikan tidak berpengaruh terhadap penyajian laporan keuangan SAK ETAP pada UMKM Barbershop. Latar belakang pendidikan berpengaruh positif signifikan terhadap penyusunan laporan keuangan SAK ETAP, dari hasil pengujian dinyatakan ditolak, artinya tidak ada pengaruh jenjang pendidikan terhadap penyusunan laporan keuangan SAK ETAP. Mayoritas latar belakang pendidikan pelaku UMKM Barbershop bukan dari akuntansi sehingga kemampuan memahami dan menyajikan laporan keuangan masih jauh memadai. Transaksi operasional masih digabungkan dengan pengeluaran pribadi pemilik. Skala usaha berpengaruh positif signifikan terhadap penyusunan laporan keuangan SAK ETAP dan hasil pengujian menyatakan ditolak, artinya tidak ada pengaruh skala usaha terhadap penyusunan laporan keuangan SAK ETAP. Kurangnya pemahaman dalam akuntansi menyebabkan skala usaha UMKM Barbershop tidak berpengaruh terhadap penyusunan laporan keuangan SAK ETAP, para pelaku usaha mayoritas hanya lulusan SMA dan bahkan SMP menjadi salah satu penyebabnya. Pengalaman usaha berpengaruh positif signifikan terhadap penyusunan laporan keuangan SAK ETAP dan hasil pengujian menyatakan diterima, artinya terdapat hubungan positif yang signifikan antara pengalaman usaha dengan penyusunan laporan keuangan SAK ETAP pada UMKM Barbershop.

\section{E. E. SIMPULAN DAN SARAN}

Berdasarkan bukti-bukti empiris yang diperoleh, ada beberapa hal yang dapat disimpulkan dari hasil penelitian ini, yaitu :

1. Tingkat pendidikan tidak berpengaruh signifikan terhadap penyusunan laporan keuangan SAK ETAP, dilihat dari nilai signifikansi lebih besar dari 0,05 yaitu 0,576. Hasil ini menunjukkan penyusunan laporan keuangan berdasarkan SAK ETAP tidak dipengaruhi dengan tingkat pendidikan.

2. Latar belakang pendidikan tidak berpengaruh signifikan terhadap penyusunan laporan keuangan SAK ETAP, dilihat dari nilai signifikansi lebih besar dari 0,05 yaitu 0,423. Hasil penelitian ini menunjukkan penyusunan laporan keuangan berdasarkan SAK ETAP tidak dipengaruhi oleh latar belakang pendidikan.

3. Skala usaha tidak berpengaruh signifikan terhadap penyusunan laporan keuangan SAK ETAP, dilihat dari nilai signifikansi lebih besar dari 0,05 yaitu 0,19. Hasil ini menunjukkan penyusunan laporan keuangan berdasarkan SAK ETAP tidak dipengaruhi dengan besarnya skala usaha. 
4. Pengalaman usaha berpengaruh positif signifikan terhadap penyusunan laporan keuangan SAK ETAP, dapat dilihat dari nilai signifikansi lebih kecil dari 5\% yaitu 0,046. Hasil penelitian ini menunjukkan bahwa penyusunan laporan keuangan berdasarkan SAK ETAP dipenagruhi oleh pengalaman usaha UMKM Barbershop.

Berdasarkan hasil penelitian yang telah dilakukan, terdapat saran dalam penelitian ini:

1. Terkait metode teknik penelitian data sebaiknya tidak hanya menggunakan kuesioner, tetapi dapat melalui teknik wawancara atau observasi sehingga data yang diperoleh lebih kompleks.

2. Dalam penyusunan kuesioner lebih banyak menggunakan berbagai referensi sebagai pembanding.

3. Diperlukan adanya sosialisai terkait pembukuan sederhana, sehingga lebih mudah dipahami oleh para pelaku UMKM Barbershop yang bukan memiliki latar belakang akuntansi.

Keterbatasan dalam penelitian ini antara lain:

1. Keterbatasan peneliti pada teknik yang digunakan dalam mengumpulkan data menggunakan kuesioner, sehingga informasi yang diperoleh mengenai penyusunan laporan keuangan berdasarkan SAK ETAP masih belum sempurna.

2. Keterbatasan waktu peneliti untuk mendapatkan data dari para pelaku UMKM Barbershop di Kota Bandarlampung khususnya Kecamatan Tanjung Senang.

3. Keterbatasan peneliti dalam menyebar kuesioner kepada pelaku UMKM Barbershop di Kecamatan Tanjung Senang, ada beberapa pelaku usaha tidak mau dimintai informasi.

Penelitian ini diharapkan mampu memberikan informasi dan pemahaman kepada para pelaku UMKM Barbershop khususnya di Kecamatan Tanjung Senang dalam penyusunan laporan keuangan SAK ETAP sekaligus sebagai bahan pertimbangan bagi UMKM dalam meningkatkan Standar Akuntansi Keuangan. Penerapan Standar Akuntansi Keuangan dalam suatu usaha dapat mempermudah pelaku usaha untuk terus memantau keadaan operasional usaha, arus keluar dan masuknya kas serta panduan untuk keberlangsungan usaha. Bagi pihak eskternal khususnya lembaga keuangan dengan melakukan penyusunan laporan keuangan SAK ETAP dapat mempermudah dalam pengajuan kredit modal usaha bagi pelaku usaha.

\section{REFERENSI}

Ambarwati, Novi Sagita., Gede Adi Yuniarti, dan Ni Kadek Sinarwati. 2015. "Pengaruh Likuiditas, Aktivitas dan Ukuran Perusahaan terhadap Profitabilitas pada Perusahaan Manufaktur yang Terdaftar di Bursa Efek Indonesia”. E-Journal S1 Ak Universitas Pendidikan Ganesha, Volume 3 No. 1. Singaraja: Universitas Pendidikan Ganesha.

Andriani, Lilya.,Antawikrama Tungga Atmaja, dan Ni Kadek Sinarwati. 2014. "Analisis Penerapan Pencatatan Keuangan Berbasis SAK ETAP pada Usaha Mikro Kecil dan Menengah (UMKM) (Sebuah Studi Intrepretatif Pada Peggy Salon)”. E-Journal S1 Ak Universitas Pendidikan Ganesha, Volume 2 No. 1. Singaraja: Universitas Pendidikan Ganesha.

Aufar, Arizali. 2014. "Faktor-Faktor yang Mempengaruhi Penggunaan Informasi Akuntansi pada UMKM (Usaha Mikro, Kecil, dan Menengah) (Survei Pada Perusahaan Rekanan PT. PLN (Persero) di Kota Bandung)". Bandung: Universitas Widyatama.

Ghozali, Imam. 2005. Aplikasi Analisis Multivariate dengan program SPSS. Semarang: Badan Penerbit Universitas Diponegoro.

Ghozali, Imam. 2011. Aplikasi Analisis Multivariate dengan Program IBM SPSS

19. Semarang: Badan Penerbit Universitas Diponegoro.

Ghozali, Imam dan Anis Chariri. 2014. Teori Akuntansi International Financing Reporting System. Semarang: Badan Penerbit Universitas Diponegoro.

Gray, C. 2006. "Absorptive Capacity, Knowledge Management and Innovation in Enterpreneural Small Firms". International Journal of Enterpreneural Behavior and Research, Volume 12 No. 6. Hal 345-360.

Hastuti, Rina.,Anita Wijayanti dan Yuli Chomsatu. 2017. "Pengaruh Jenjang Pendidikan dan Pemahaman Teknologi Informasi Terhadap Penyajian Laporan Keuangan Berdasarkan SAK ETAP (Studi Kasus di Kampung Batik Laweyan)". E-Journal Universitas Islam Batik Surakarta, Volume 2 No. 02 2017: Universitas Islam Batik Surakarta.

Holmes, Scott dan Des Nicholls. 1988. “An Analysis of the Use of Accounting Information by Australian Small 
Business". Journal of Small Bussiness Management.

Ikatan Akuntan Indonesia. 2009. Standar Akuntansi Keuangan Entitas Tanpa Akuntabilitas Publik. Jakarta: Dewan Standar Akuntansi Keuangan.

Kholis, Irwan Nur. 2014. "Tingkat Pendidikan, Skala Usaha, Pengalaman Usaha, dan Masa Jabatan Berpengaruh Terhadap Penerapan Laporan Informasi Akuntansi Pada Usaha Kecil Menengah (Studi Kasus Pada UKM Tepung Tapioka di Desa Ngemplak Kidul Kecamatan Margoyoso Kabupaten Pati)". Semarang: Universitas Dian Nuswantoro.

Oktaritama, Edningsari Dewi. 2015. "Analisis Faktor-Faktor Yang Mempengaruhi Pemahaman Bagian Akuntansi Koperasi Atas Standar Akuntansi Keuangan Entitas Tanpa Akuntabilitas Publik (SAK ETAP) (Studi Kasus Pada Koperasi Di Kabupaten Purworejo)". Skripsi. Semarang: Universitas Diponegoro.

Prawesti, Ita. 2017. "Faktor-Faktor yang Mempengaruhi Pemahaman UMKM Dalam Menyusun Laporan Keuangan Berdasarkan SAK ETAP”. Jurnal Fakultas Ekonomi Universitas PGRI Yogyakarta, Vol 7. Hal 17-31.

Quaqli, Alberto and Paola Paolini. 2012. How is the IFRS for SME accepted in the

European Context? An Analysis of the Homogenity Among European Countries, Users and Prepares in the European Commision Questionnaire". Elsevier Journal.

Rudiantoro, Rizki dan Sylvia Veronica Siregar. 2012. "Kualitas Laporan Keuangan UMKM serta Prospek Implementasi SAK ETAP”. Jurnal Akuntansi dan Keuangan Indonesia, Volume 12 No. 1. Hal 1-21 Jakarta:Universitas Indonesia.

Sanusi, Anwar. 2016. Metodologi Penelitian Bisnis. Jakarta: Salemba Empat.

Seftianne. 2001. "Faktor-Faktor yang Mempengaruhi Struktur Modal pada Perusahaan Publik Sektor Manufaktur". Jurnal Bisnis dan Akuntansi. Volume 13 No. 1.

Solovida, Grace Tiana. 2003. "Analisis Faktor-Faktor yang Mempengaruhi Penyiapan dan Penggunaan Informasi Akuntansi pada Perusahaan Kecil dan Menengah”. Tesis. Semarang: Program Studi Magister Akuntansi Universitas Diponegoro.

Tuti, Rias dan S, Patricia F Dwijayanti. 2014. "Faktor-Faktor yang Mempengaruhi Pemahaman UMKM Dalam Menyusun Laporan Keuangan Berdasarkan SAK ETAP”. The $7^{\text {th }}$ NCFB and Doctoral Colloquium 2014. Fakultas Bisnis dan Pascasarjana UKWMS.

Undang-Undang Republik Indonesia Nomor 20 Tahun 2008 tentang Usaha Mikro, Kecil, dan Menengah. http://www.bi.go.id/id/tentang-bi/uu-bi/Documents/ UU20Tahun2008UMKM.pdf (10 Februari 2018).

Wijayanti, Annisa Fitri Dwi. 2015. "Faktor-Faktor yang Mempengaruhi Persepsi Atas Implementasi Standar Akuntansi Keuangan Tanpa Akuntabilitas Publik Pada Koperasi”. Skripsi. Semarang: Universitas Diponegoro. 